\title{
CORRECTION:
}

Rhamnus cathartica L. Is Not Prunus nigra Ait.

KEITH SHAW, Box 364, Cardston, Alberta TOK 0K0

The report of Canada Plum (Prunus nigra Ait.) in Alberta was based on material collected without flowers or fruit from south Alberta. 12 The preliminary identification was made from floral manuals only, with later verification through comparison with known Prunus nigra material at the Vascular Plant Herbarium of the Canada Department of Agriculture, Ottawa.

Several years later these south Alberta plants flowered and fruited. Much to my dismay, it was not Prunus nigra, but an adventive species hitherto unreported for Alberta to which Prunus nigra bears an uncanny resemblance, Rhamnus catharica, the European Buckthorn. This species was introduced from Europe and is now found growing wild as a coarse shrub

\section{Rhamnus cathartica}

European Buckthorn

spine-tipped branchlets

no terminal bud

toothed leaves, thin and fragile

leaves dark green above, lighter below

leaves tend toward opposite or clustered

leaf margin glandular

scaly winter buds

twigs slender reddish-brown

bark smooth, dark greyishbrown becoming scaly with age

short crooked trunk divided at or just above ground

crown irregular; slender zig-zag branches

small tree or large shrub or small tree in the valley of Lee Creek at Cardston, Alberta. Two ornamental plantings are now also known for the town of Cardston.

When the plants are in flower or fruit no real difficulty is encountered in correctly identifying European Buckthorn which has flowers small, greenish, perfect, regular, perigynous with an annuar disk; sepals 4 ; petals much reduced to wanting; stamens 4 , inserted on the disk opposite the rudimentary petals; pistil 1 , the ovary inserted in the disk, 4-loculed, each locule 1-seeded; fruit juicy, berry-like and bitter.

However, a comparison of vegetative characteristics will show how readily a person unfamiliar with these two species might make an error.

Prunus nigra

Canada Plum

thorn-like twigs

no terminal bud

double-toothed leaves, thin and fragile

leaves dull dark green above, paler beneath

leaves clustered

leaf margin glandular

scaly winter buds

twigs slender smooth reddish-brown

bark black with greyish lenticels, splitting vertically, scaly with age

short crooked trunk divided at or just above ground

crown narrow and flat-topped; slender, twisted, zig-zag branches

small tree 
I regret any inconvenience this erroneous report of Prunus nigra has caused. I will gladly supply herbarium specimens of south Alberta Rhamnus cathartica on request.

'CODY, W. J. and SHAW, K. 1973. Canada
Plum in southwestern Alberta. Blue Jay 31:217-219.

${ }^{2}$ SHAW, Robert K. 1976. A taxonomic and ecological study of the riverbottom forest on St. Mary River, Lee Creek and Belly River in southwestern Alberta, Canada. Great Basin Naturalist 36:243271.

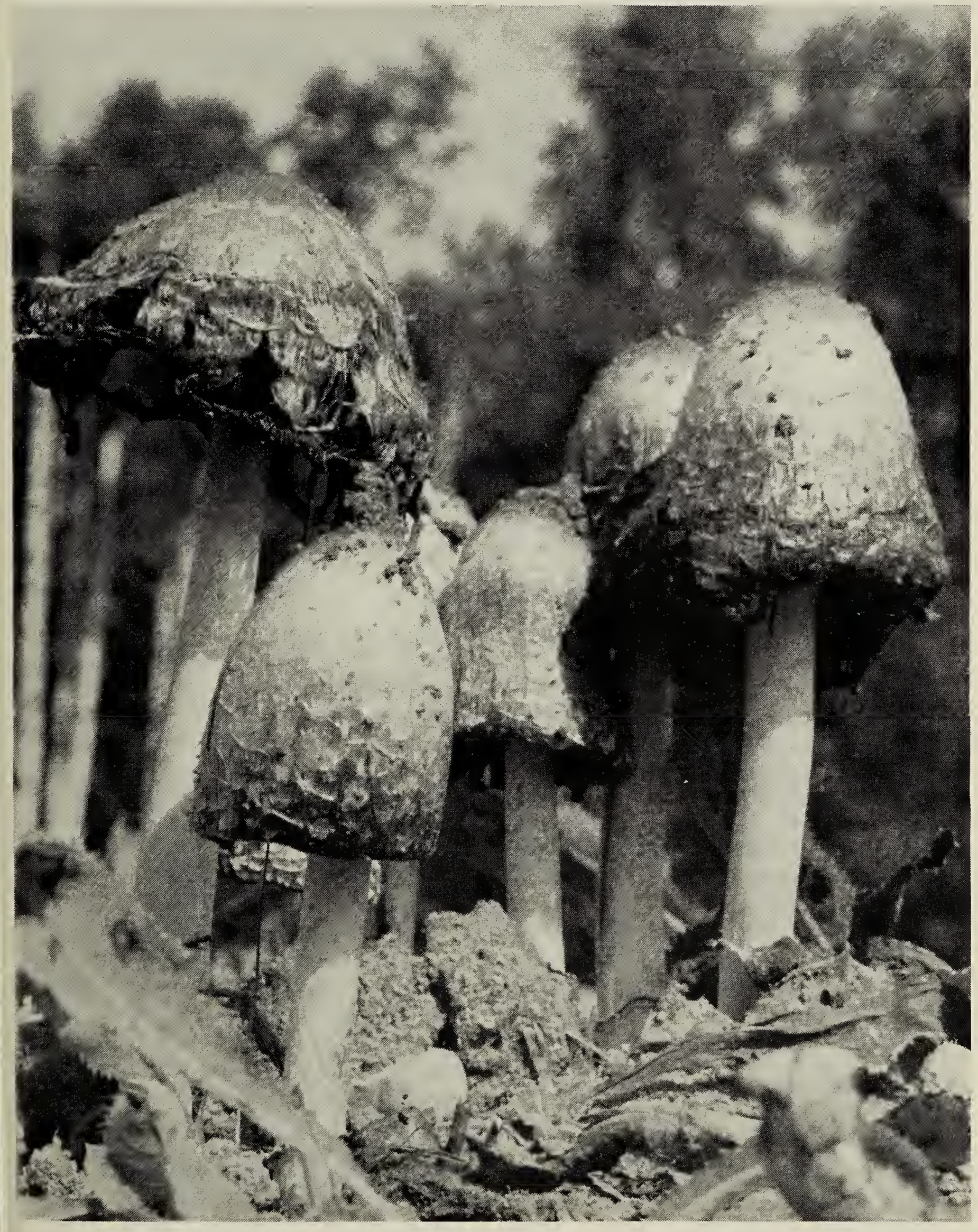

